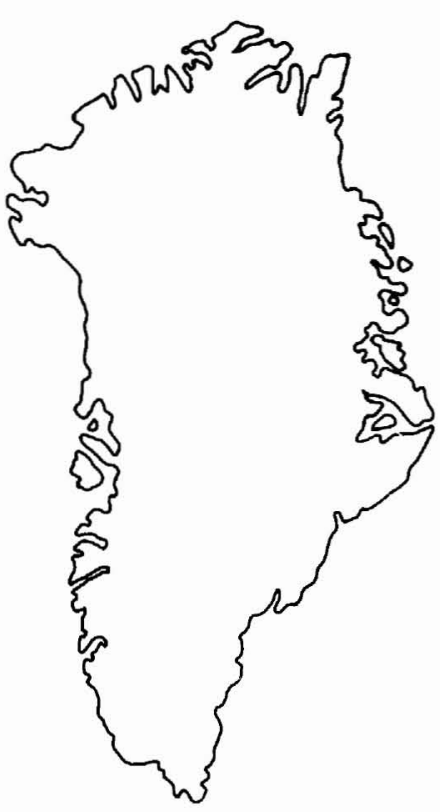

\title{
Ordovician graptolite biostratigraphy in North Greenland
}

\author{
Merete Bjerreskov
}

\begin{abstract}
Up to $500 \mathrm{~m}$ of black-bedded cherts and mudstones with thin turbidites and thick local beds of redeposited limestone and chert conglomerates were deposited during the Ordovician in North Greenland, along the southern margin of an east-west trending deep-water trough forming a continuation of the Franklinian Basin of Arctic Canada. A large collection of Ordovician graptolites has recently been obtained from this clastic sequence. The graptolite fauna, not collected in continuous sections, compares particularly well with the fauna from the Canadian Cordillera and for the most part is interpreted in terms of the established biozones from that area. The faunas are also correlated with the Australian zonal sequences.

In North Greenland neither the Cambrian-Ordovician boundary nor the Ordovician-Silurian boundary can be precisely demarcated by graptolites. The following graptolite biozones are represented: Anisograptus, Adelograptus \& Clonograptus, $T$. approximatus, $P$. fruticosus, $D$. bifidus, I. victoriae lunatus, ? I. victoriae victoriae, ? I. victoriae maximus, Oncograptus, P. tentaculatus, ? 'D.' decoratus, ? H. teretiusculus, $N$. gracilis, C. bicornis, ? O. amplexicaulis, O. quadrimucronatus, D. ornatus and ? P. pacificus.

The relationship of the North Greenland graptolites to the Ordovician 'Pacific faunal realm' and oceanic graptolite biofacies is briefly discussed.
\end{abstract}

M. B., Geological Museum, Øster Voldgade 5-7, DK-1350 Copenhagen K, Denmark.

In early Palaeozoic time the Franklinian Basin of the Canadian Arctic Islands extended from northern Ellesmere Island across North Greenland. In Greenland the exposed segment of the basin is approximately 800 $\mathrm{km}$ long and has a maximum preserved north-south width of $200 \mathrm{~km}$. Two major depositional environments are represented. A deep-water trough was situated along the northern coast of Greenland and fringed to the south by a shallow shelf dominated by carbonate sediments. The deep-water sequence attains an exposed thickness of at least $8 \mathrm{~km}$ and comprises siliciclastic and calcareous turbidites with subordinate mudstones, whereas on the platform an approximately $3 \mathrm{~km}$ thick sequence of mainly carbonates accumulated (e.g. Higgins et al., in press).

During the Ordovician up to $500 \mathrm{~m}$ of deep-water clastic sediments, mainly black-bedded cherts and mudstones with thin turbidites, and with thick local beds of redeposited limestone and chert conglomerates, were deposited along the southern margin of the trough. On the platform to the south an up to $1 \mathrm{~km}$ thick sequence of carbonates was deposited. The stratigraphy and geological development of the Ordovician have recently been described by Trettin \& Balkwill (1979), Peel (1982), Friderichsen et al. (1982), Surlyk \& Hurst (1984), Higgins \& Soper (1985) and Higgins et al. (in press).

The tectonic and sedimentological development of the Ordovician sequence was included in basin evolution stages 4 and 5 by Higgins et al. (in press). From the Late Cambrian to the Middle Ordovician (stage 4) the sedimentation was dominated by progradational platform and starved basin deposits. There was a differential subsidence and southwards expansion of the eastwest deep-water trough and uplift of eastern North Greenland. To the west outermost shelf and slope rocks outcrop between Nyeboe Land and J. P. Koch Fjord (fig. 1). Here the uppermost unit from the upper Middle Cambrian to lowermost Ordovician sequence is between 150 and $300 \mathrm{~m}$ thick and composed of dark lime mudstone, with lime turbidites to the east and thinbedded grey limestones and yellow dolomites to the west. Towards the north the sequence passes into chert and cherty shales less than $100 \mathrm{~m}$ thick, indicating slope environments. To the east, in southern Johannes V. Jensen Land, Amundsen Land and the region around 


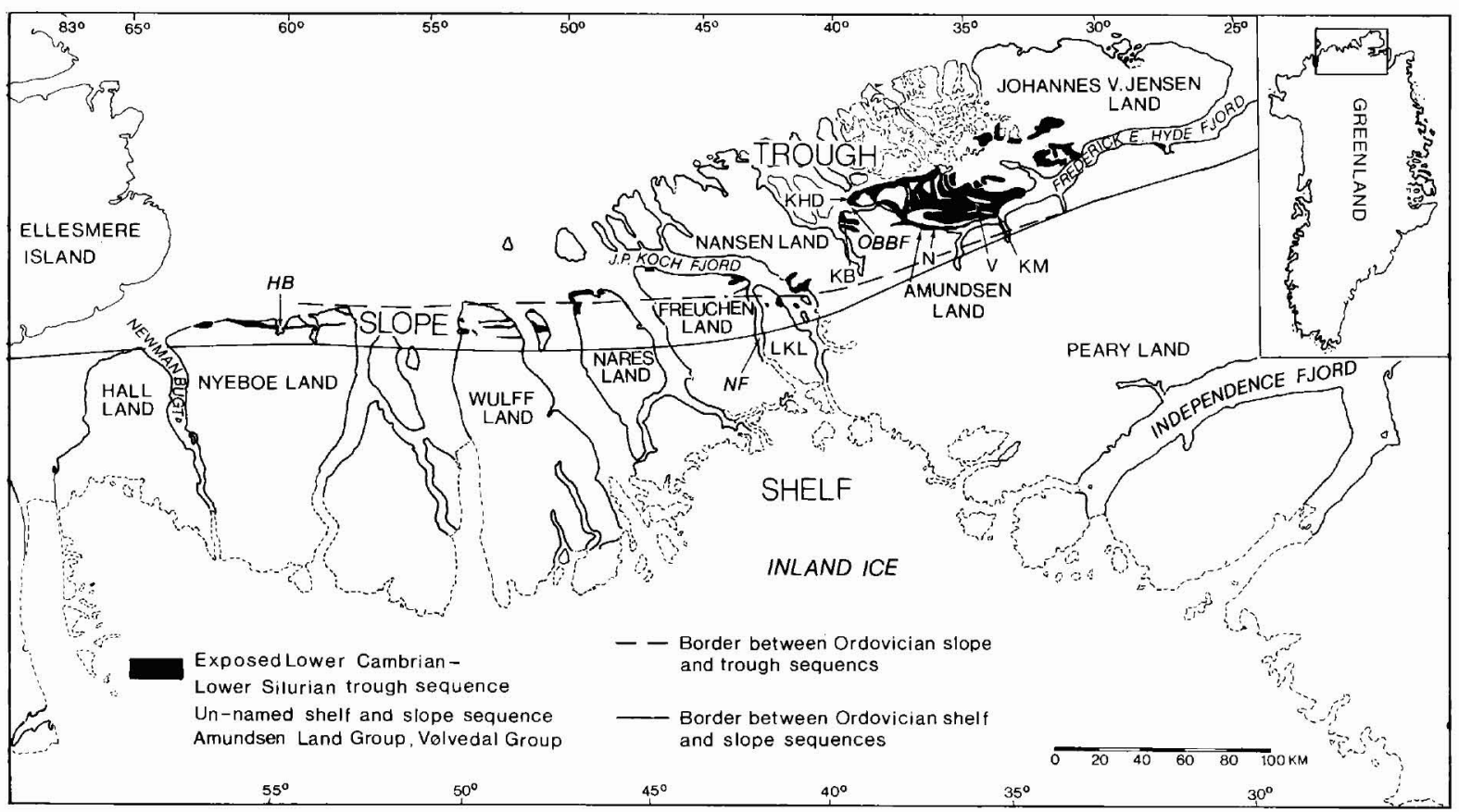

Fig. 1. Map of North Greenland showing the position of Ordovician slope and trough sequences and important graptolite localities. From Geological Map of North Greenland (Bengaard \& Henriksen, 1986; Higgins et al., in press). HB Hand Bugt; KB Kap Bopa; KHD Kap Holger Danske; KM Kap Mjølner; LKL Laugc Koch Land; N Nordpasset; NF Navarana Fjord; OBBF O.B. Bøggild Fjord; V Vølvedal.

Frederick E. Hyde Fjord, an outer slope and troughfloor sequence (600-700 m thick) with dark mudstones, cherts, turbidites including thick sandstone sequences and base-of-slope conglomerates was deposited.

From the Middle Ordovician to Early Silurian (stage 5) the basin can be divided into a stable platform and a starved slope and trough. In this period carbonate deposition continued to build up on the platform. North of the scarp-like platform margin, in the area from Nyeboe Land to J. P. Koch Fjord, very restricted amounts of sediment were deposited on a broad slope (starved slope). Here Cambrian - Lower Ordovician strata are overlain by a sequence of chert and cherty shales, with partly chertified siltstones, black limestones and dolomitic mudstones. The starved slope sediments are generally between 50 and $150 \mathrm{~m}$ thick. Further north in the deep-water trough, deposition was still slow but greater than in the slope areas. The Ordovician trough sediments outcrop in southern Johannes V. Jensen Land, including Amundsen Land and along the south side of Frederick E. Hyde Fjord. The sedimentary facies are mainly radiolarian cherts and black and green mudstones, including thin turbidites. In the Middle Ordovician an up to $200 \mathrm{~m}$ thick sequence of carbonate conglomerates was deposited over wide areas of Amundsen
Land. During the late Middle Ordovician the conglomerate and turbidite deposition faded out and, in the Late Ordovician, the slow sedimentation of fine-grained deposits continued. Starved basin deposition was terminated by basin expansion, and sandy turbidite deposition started in the Late Llandovery.

During the Ordovician the graptolites are the only age-diagnostic fossils in the deep-water sediments along the southern margin of the trough. Here other fossils are represented by rare ceratiocarid fragments.

Until recently, information on Ordovician graptolites in North Greenland has been sparse. Poulsen (1927) reported 'Didymograptus bifidus' and 'Phyllograptus angustifolius' from the Nunatami Formation within the platform sequence in Washington Land, western North Greenland. Cowie (1961) reported the presence of $D i$ dymograptus from eastern North Greenland. In a preliminary report by Dawes \& Soper (1970) an Ordovician age was suggested for graptolites found in Peary Land, central North Greenland. The fauna was listed by Bjerreskov in Bjerreskov \& Poulsen (1973) and reported to be of Tremadoc and Arenig ages and was referred to the 'Pacific' graptolite fauna.

Between 1978 and 1985, during the systematic regional investigation and mapping of North Greenland 


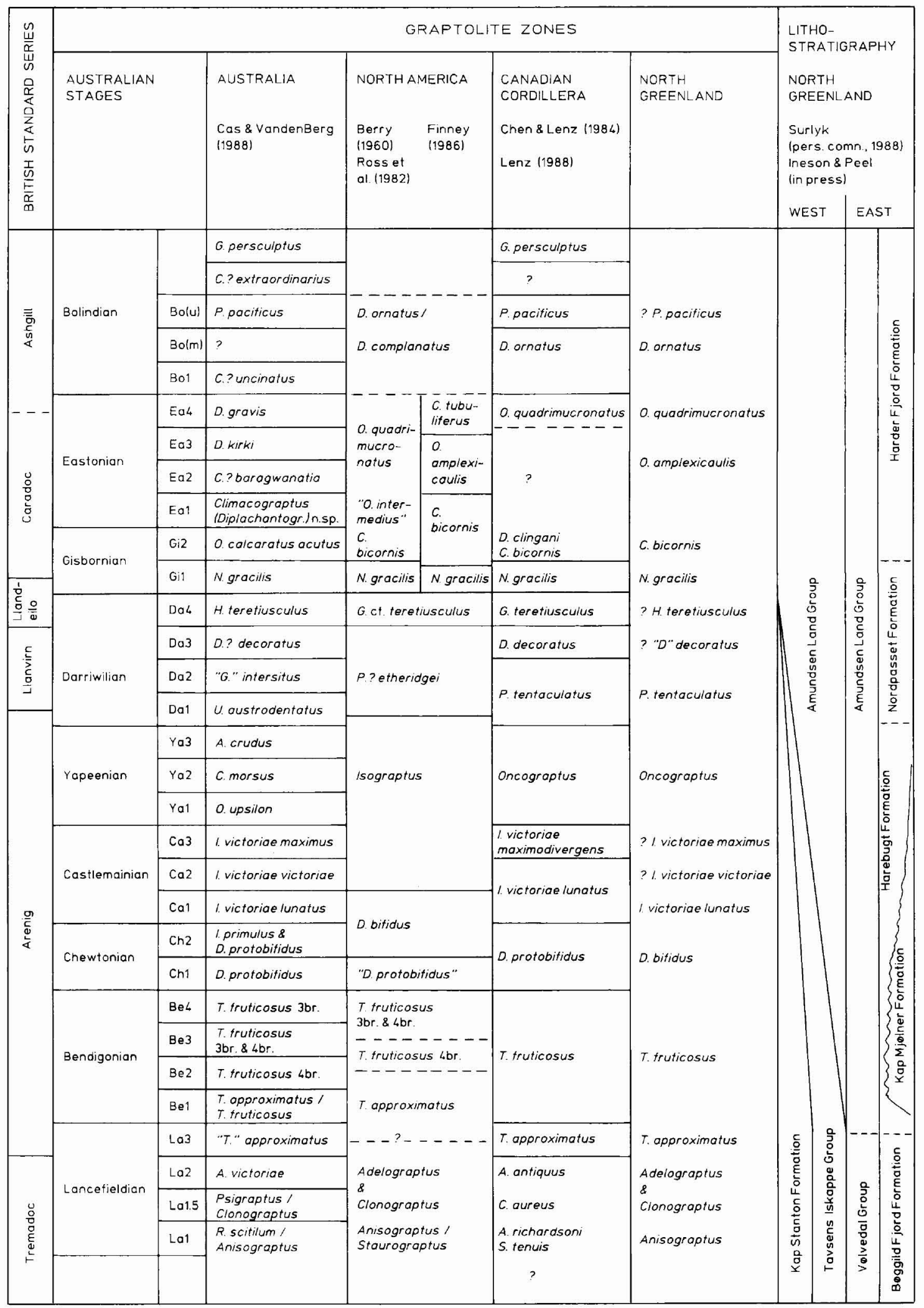

Fig. 2. Ordovician lithostratigraphy and graptolite zones in North Greenland correlated with the graptolite zonations of Australia, Canadian Cordillera and the United States. WEST $=$ west of $40^{\circ} \mathrm{W}$, EAST $=$ east of $40^{\circ} \mathrm{W}$. 
by the Geological Survey of Greenland, about 85 samples with Ordovician graptolites were collected. Ordovician graptolite facies in North Greenland are principally confined to the deep-water basin margin and outer slope sediments in the Franklinian Basin sequence; only two graptolite samples have been found in the equivalent platform rocks. Some preliminary age determinations based on these graptolites were reported in Surlyk et al. (1981), Friderichsen et al. (1982), Higgins \& Soper (1985), Sønderholm et al. (1987) and Bjerreskov (1988).

\section{Lithostratigraphy}

The Ordovician deep-water clastic sediments in North Greenland are lithostratigraphically subdivided into two groups, the Vølvedal and Amundsen Land Groups, with the type areas situated in the eastern part of central North Greenland (fig. 2; Friderichsen et al., 1982). The Vølvedal Group extends down into the Cambrian but graptolites of Late Tremadoc age have been collected from near the top. It is subdivided into three formations, of which only the uppermost O. B. Bøggild Fjord Formation is relevant to the present investigation; it is mainly of Tremadoc age. The formation consists of quartzitic turbidites alternating with thin units of black mudstones (F. Surlyk, personal communication).

The overlying Amundsen Land Group, deposited during a period of basin starvation, extends from the end of the Tremadoc to the Early Silurian (Friderichsen et al., 1982). The group is subdivided into four formations (Higgins et al., in press; F. Surlyk, personal communication). The lowermost formation is the Tremadoc - Late Arenig Harebugt Formation, which consists of black mudstones and cherts interbedded with sandstone turbidites, in all 100-200 $\mathrm{m}$ thick. This formation locally interfingers with the Kap Mjølner Formation, composed mainly of resedimented limestone conglomerates, with a maximum formation thickness of $150 \mathrm{~m}$ and without any graptolites. The Nordpasset Formation corresponds in age to the latest Arenig and earliest Caradoc and consists mainly of green-grey ribbon cherts, chertified mudstones and siltstone. The formation is 170 $m$ thick in the type section. The Early Caradoc to Early Silurian Harder Fjord Formation consists of black chert and mudstone and is estimated to be $150-200 \mathrm{~m}$ thick. All four formations have type sections in eastern areas of central North Greenland, and their ages are indicated by the graptolites.

In western North Greenland and western areas of central North Greenland, approximately between central J. P. Koch Fjord and northern Nyeboe Land, the Ordovician, starved, outer slope and basin sequences are referred to two formations of the Tavsens Iskappe
Group and Amundsen Land Group. The Kap Stanton Formation of the Tavsens Iskappe Group has yielded graptolites from the Llanvirn Zone in the uppermost metres (Ineson \& Peel, in press; Higgins et al., in press). The overlying Amundsen Land Group sequence is referred entirely to a new formation of the group (Higgins et al., in press) and ranges in age from the Tremadoc to the Late Llandovery. The starved basin sequence of this region consists largely of cherts and cherty shales, is from 50 to $150 \mathrm{~m}$ thick and has yielded the most complete successions of graptolites.

\section{Biostratigraphy}

The graptolites occur in dark shales, mainly as flattened carbon films; tectonic deformation is not uncommon. The flattening is so pronounced that detailed morphological structures cannot be observed. Graptoloid taxonomy is currently under revision, and the classifications of Fortey \& Cooper (1986), Mitchell (1987) and Williams \& Stevens (1988) have been followed here. Most of the graptolites are so badly preserved that they are unsuitable for photography; selected graptolites are illustrated by mainly camera lucida drawings (figs 4-7).

Only scattered graptolite samples were collected. Some samples are placed in profiles, but no section has been collected bed by bed. A few samples from scree material include graptolite species suggesting different ages. Consequently the present graptolite material does not allow evaluation of the vertical range of the taxa, and no full biozones and zonal boundaries can be defined. For each sample a faunal list has been made and compared with earlier reported assemblages from established graptolite zones in other areas. Thus the graptolite species listed in the stratigraphic scheme (fig. 2) indicate faunal assemblages which are correlated with formal biozones; they do not represent complete graptolite zones. Many of the samples contain only a few graptolites or graptolites which are badly preserved; the taxonomic position of many of these graptolites, and consequently their stratigraphical level, cannot be indicated.

Graptolite faunas representing most of the internationally recognised Ordovician graptolite zones have been found in North Greenland. The graptoliferous succession is most likely complete, although this cannot be proved by the present scattered samples. There is currently no evidence in the graptolite sequences for lowermost and uppermost Ordovician rocks, i.e. the transitions Cambrian-Ordovician and Ordovician-Silurian.

The most complete graptolite successions in North 
Greenland have been found in the region west of $40^{\circ} \mathrm{W}$, whereas east of $40^{\circ} \mathrm{W}$ mainly the lower part of the Ordovician comprising the Anisograptus to the $H$. teretiusculus zones has been recognised. Late Ordovician graptolite faunas have only been found in southern Johannes V. Jensen Land (Surlyk et al., 1981) and at Kap Bopa, Peary Land. The apparent bias in graptolite distribution is most probably due to the scattered nature of the collections in the thick trough sequence of southern Johannes V. Jensen Land. In the more western areas the graptolite-bearing, 'starved', outer shelf and slope sequence is much thinner, more accessible and has been more systematically collected.

In terms of overall inter-regional graptolite correlation the North Greenland graptolite faunas appear to be most similar to those described from the Canadian Cordillera region, especially northern Yukon. Consequently the zones established in that area have been used as the basis of the zonal scheme from North Greenland. The Canadian Cordillera zonation is based on faunas listed in Jackson $(1974,1975)$, Lenz \& McCracken (1982), Lenz \& Chen (1985) and Lenz \& Jackson (1986). The column in fig 2. is compiled from these papers, which were summarised in Chen \& Lenz (1984) and Lenz (1988). However, there are some slight modifications based on the more recent descriptions of Finney (1986) and Williams \& Stevens (1988) which apparently can be applied to the graptolites from North Greenland. These changes are mentioned in the appropriate descriptions of the graptolite zones below. Canadian Cordillera sequences have been compared with the Australasian graptolite sequences (Lenz, 1988). The Australasian stages and zones included in the scheme (fig. 2) are from Cas \& VandenBerg (1988). The North Greenland graptolite fauna is also similar to Ordovician graptolite assemblages from other parts of North America (Berry, 1960; Ross \& Berry, 1963; Carter \& Tailleur, 1984; Finney, 1986; Williams \& Stevens, 1988). The Ordovician graptolite zonation (fig. 2) in the United States is taken mainly from Ross et al. (1982), with some changes in accordance with the revision of Finney (1986).

All figured specimens are deposited in the Geological Museum, Copenhagen (MGUH prefix).

\section{Anisograptus Zone}

The Cambrian-Ordovician transition has not been seen in the graptolitiferous sequence. The presumably oldest recorded fauna is represented by GGU sample 217749 from O. B. Bøggild Fjord (fig. 1). Here only Rhabdinopora? and Anisograptus sp. (figs 4A, B, G) have been recorded.
The presence of Anisograptis forms is characteristic of the early Tremadoc (e.g. Berry, 1960; Cooper \& Stewart, 1979; Erdtmann, 1988). Strata with a dominance of the triradiate Anisograptus plexus were referred to Assemblage 2 by Cooper (1979b), corresponding to La1 in the Australian sequence.

\section{Adelograptus \& Clonograptus Zone}

The zone name was defined in Texas (Berry, 1960) and corresponds to La1.5 and $\mathrm{La} 2$ in the Australian sequence and is represented by at least four samples in the Greenland material. One of the samples (GGU 313122) contains clonograptids (?adelograptids) which are somewhat similar to Clonograptus sp. 1 (fig. 4E) and Clonograptus sp. 3 (fig. 4C) in Cooper \& Stewart (1979). Both forms were reported from La1.5. The fauna also includes Adelograptus clarki (Hall) (fig. 4F), reported from La2 and La3 (Cooper, 1979a).

Three other samples include Dictyonema pulchellum Hall, Clonograptus sp. (fig. 4D), Paradelograptus antiquus (Hall) (fig. 4R), Temnograptus magnificus Pritchard, Tetragraptus sp. as the most important species. These species all indicate a high level in the Tremadoc, corresponding to La2 and the A. antiquus Zone of Jackson (1974). Clonograptus ? n. sp. (fig. 3B) is also frequent. The species is similar to Clonograptus flexilis (Hall) and was listed as the latter by Bjerreskov in Bjerreskov \& Poulsen (1973).

\section{Tetragraptus approximatus Zone}

The zone is defined by the frequent occurrence of Tetragraptus approximatus approximatus (Nicholson) (fig. 3D), generally in association with Tetragraptus acclinans Keble (fig 3A) (in GGU 311308, 313123, 319793, 319794). Further associates are Clonograptus sp., Adelograptus sp., Paradelograptus sp., Tetragraptus quadribrachiatus Hall (fig. 3C), Tetragraptus sp. and Didymograptus sp. Etagraptus ?harti (Hall) (fig. 40) is found in GGU 313125 with T. approximatus. Both $T$. approximatus and $T$. acclinans are reported to range into the overlying $P$. fruticosus Zone, e.g. in Arctic Canada (Lenz \& Jackson, 1986), but are much less common at this level. It is possible, therefore, that some of the present samples might represent the $T$. fruticosus Zone.

Graptolites indicative of the T. approximatus assemblage have been found in many samples (e.g. GGU $311308,313123,319793$ and 319794), and this assemblage is apparently widespread and well developed throughout North Greenland. T. acclinans was reported from the T. approximatus and T. akzharensis Zones in 

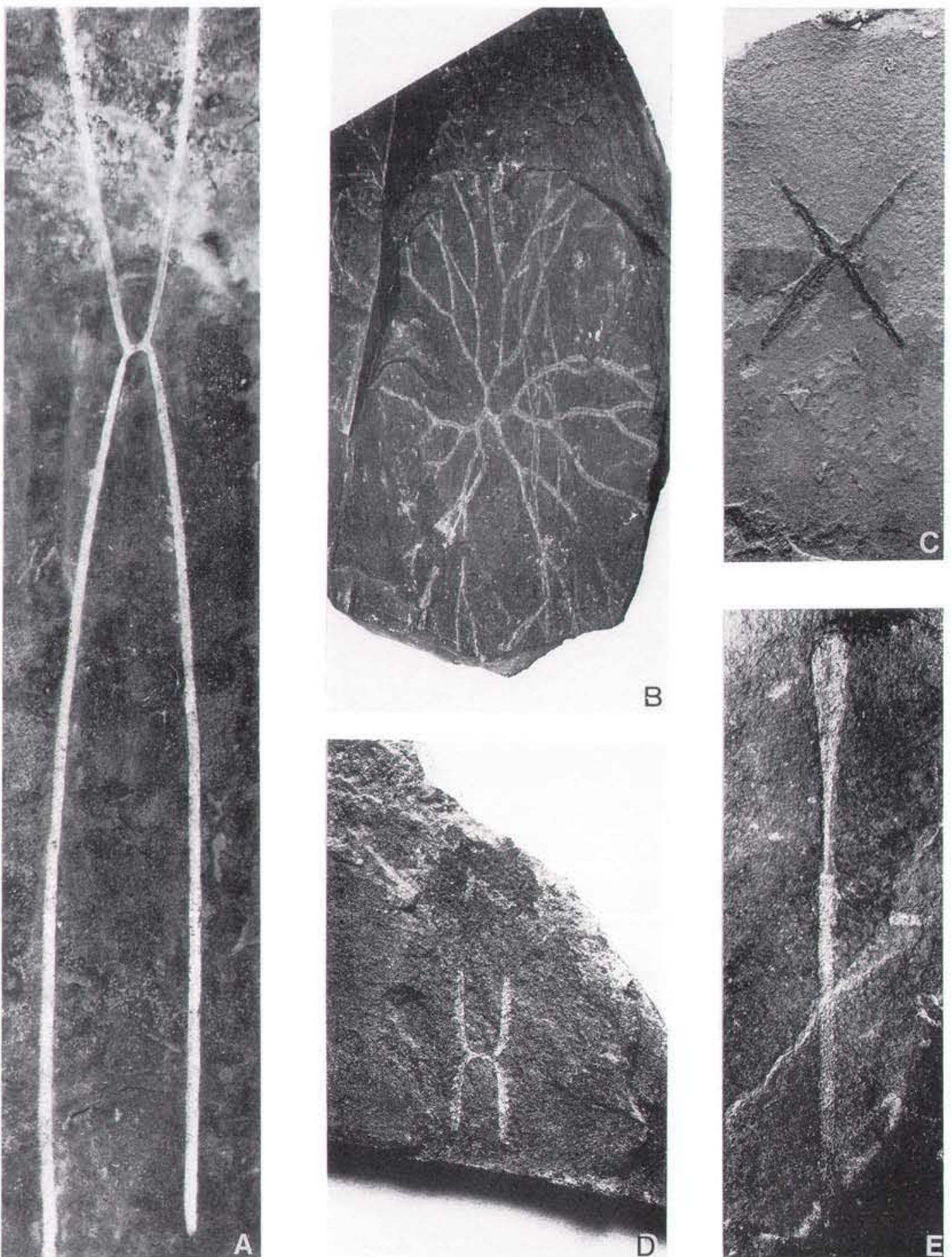

Fig. 3. A. Tetragraptus acclinans Keble, very large specimen. MGUH 19362 from GGU 319794, northern Nyeboe Land. $\times 0.57$. B. Clonograptus n. sp. ?. MGUH 19363 from GGU 53491.10, north of Harebugt, Peary Land. C. Tetragraptus quadribrachiatus Hall. MGUH 19364 from GGU 53485.2, Kap Bopa, Peary Land. D. Tetragraptus approximatus approximatus (Nicholson). MGUH 19365 from GGU 319815, northern Nyeboe Land. E. Climacograptus (Climacograptus) tubuliferus Lapworth. MGUH 19366 from GGU 319681, Nares Land. figs B-E, nat. size.

Newfoundland (Williams \& Stevens, 1988). In North Greenland it is associated with the very frequent $T$. approximatus, and Tetragraptus akzharensis Tzaj has not been observed. Consequently the $T$. akzharensis Zone defined by Williams \& Stevens $(1987,1988)$ cannot be distinguished in the present material. 

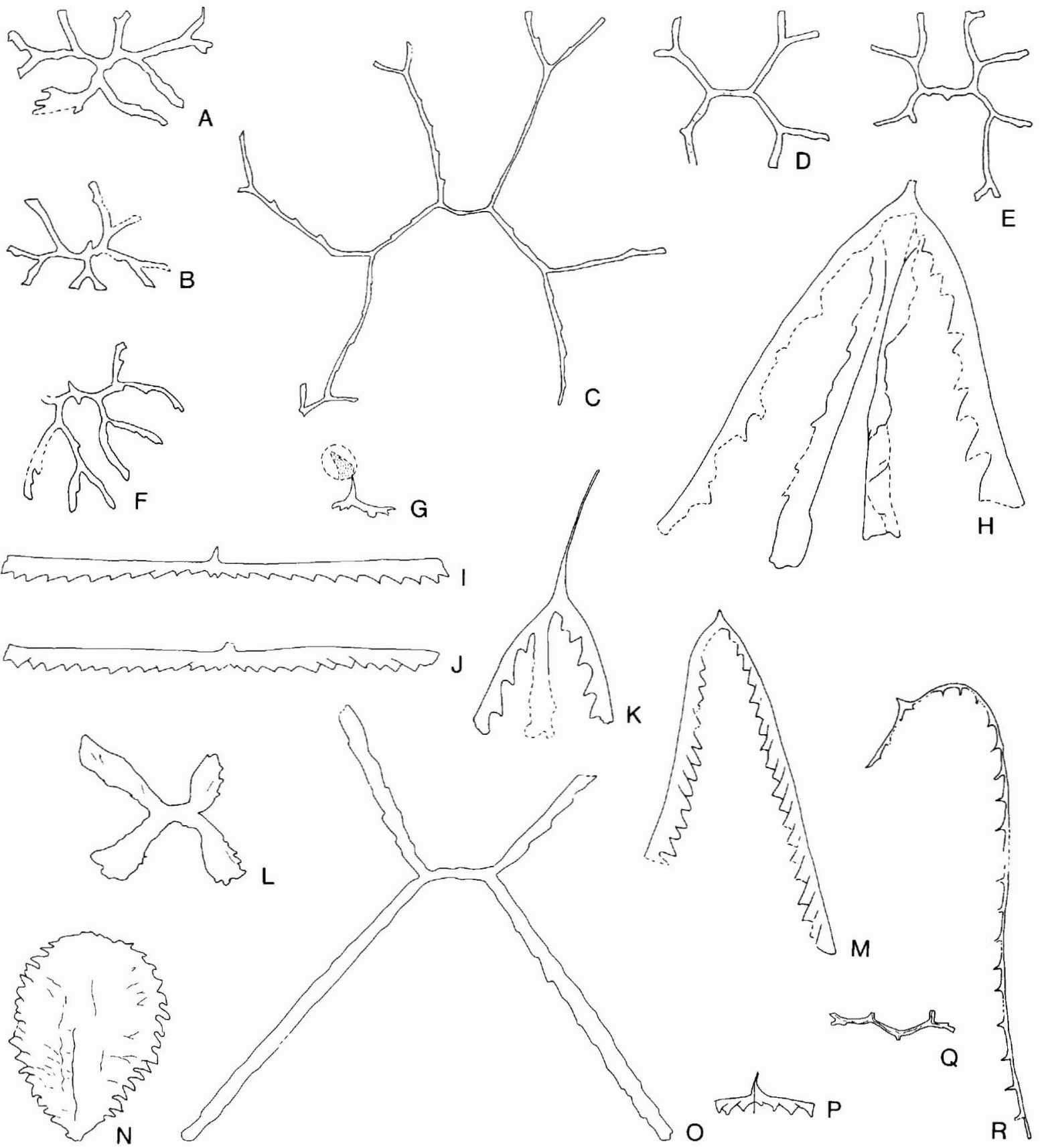


\section{Pendeograptus fruticosus Zone}

This zone is here defined by the presence of Pendeograptus fruticosus (Hall). The index species, however, is sparsely represented, as only one specimen with four stipes (fig. 4H) and two three-stiped forms (fig. 4K) has been recorded. Didymograptus (Expansograptus) extensus (Hall) (fig. 4I) and Didymograptus (Expansograptus) similis (Hall) (fig. 4J) from GGU 217745 are probably from this level (cf. Williams \& Stevens, 1988). The scanty material of the index species does not allow any separation of a lower 4-branched $P$. fruticosus Zone and an overlying 3-branched zone, e.g. as in Ross \& Berry (1963) and VandenBerg (in Webby et al., 1981). Recently this subdivision was abandoned by Williams \& Stevens (1988) who regarded the number of branches as most likely an artefact of preservation.

\section{Didymograptus bifidus Zone}

Only GGU 217715 from the Frederick E. Hyde Fjord region carries a graptolite fauna which can be referred to the D. bifidus Zone of Williams \& Stevens (1988), corresponding to the $D$. protobifidus Zone of Cooper (1979a) and Lenz \& Jackson (1986). The zonal index name was changed by Williams \& Stevens (1988) who did not recognise the stratigraphic variation within $D$. bifidus - D. protobifidus described by Fortey \& Cooper (1982).

The present material includes few specimens of Didymograptus (Didymograptellus) bifidus (Hall) (fig. 4M) which have the slender form of D. 'protobifidus' of Fortey \& Cooper (1982). The sample also includes Tetragraptus? amii Elles \& Wood, (fig. 4L), Tetragraptus ?reclinatus abbreviatus Bouček, Phyllograptus?densus Törnquist (fig. 4N), Phyllograptus?, Didymograptus cf. D. artus Elles \& Wood, Didymograptus (Expansograptus) sp., Sigmagraptus sp. (fig. 4Q) and Laxograptus?.
Poulsen (1927) reported D. bifidus and Pseudophyllograptus angustifolius (Hall) from the Nunatami Formation in Washington Land. D. bifidus reported by Poulsen (1927) is similar to the wide specimens of $D$. bifidus reported by e.g. Williams \& Stevens (1988), but accordingly does not give any precise identification of the stratigraphic horizon.

GGU 206376 from the Nunatami Formation contains Didymograptus (Expansograptus) ?nitidus (Hall) indicating a level from the $P$. fruticosus Zone (Williams \& Stevens, 1988) to the D. bifidus, Middle Arenig, approximately corresponding to the Chewtonian-Castlemainian interval in the Australian sequence (Fortey \& Owens, 1987).

\section{Isograptus victoriae lunatus Zone}

Two GGU samples $(217829,313081)$ include Isograptus victoriae lunatus Harris (fig. 5A, B) which is regarded as indicator of the internationally well recognised I. victoriae lunatus Zone (Cooper, 1979a; Lenz \& Jackson, 1986; Williams \& Stevens, 1988). The index species is associated with Pseudophyllograptus? angustifolius (Hall), T. ?reclinatus abbreviatus, (fig. 5F), Didymograptus? and Isograptus sp. The present sparse material does not add any new information to this stratigraphic level.

\section{? Isograptus victoriae victoriae Zone}

Only GGU 217716 contains Isograptus victoriae victoriae Harris (fig. $5 \mathrm{E}$ ) and this occurs together with Didymograptus? With the limited material available, the presence of this zone is inconclusive. The I. victoriae victoriae Zone was recorded by Webby et al. (1981) and Williams \& Stevens (1988), but was not distinguished by Cooper (1979a) and Lenz \& Jackson (1986). Thus it might be a zone with a limited, possibly regional, strati-

Fig. 5. A, B. Isograptus victoriae lunatus Harris A. MGUH 10385 from GGU 313081. B. MGUH 19386 from GGU 313081. C. Tetragraptus ?serra (Brongiart). MGUH 19387 from GGU 313173. Navarana Fjord, Freuchen Land. D., H. Isograptus? dilemma Williams \& Stevens. D. MGUH 19388 from GGU 217807. Frederick E. Hyde Fjord, Johannes V. Jensen Land. H. MGUH 19389 from GGU 217829. Frederick E. Hyde Fjord, Johannes V. Jensen Land. E. Isograptus victoriae victoriae Harris. MGUH 19390 from GGU 217716. Frederick E. Hyde Fjord, Johannes V. Jensen Land. F. Tetragraptus ?reclinatus abbreviatus Bouček. MGUH 19391 from GGU 217829. Frederick E. Hyde Fjord, Johannes V. Jensen Land. G. Didymograptus cf. D. compressus Harris \& Thomas. MGUH 19392 from GGU 313175, West side of Navarana Fjord. I. Skiagraptus ?gnomonicus (Harris \& Keble). MGUH 19393 from GGU 319799. Frederick E. Hyde Fjord, Johannes V. Jensen Land. J. Xiphograptus?declinatus Williams \& Stevens. MGUH 19394 from GGU 217760. North of Vølvedal, Johannes V. Jensen Land. K. Oncograptus upsilon biangulatus Harris \& Keble. MGUH 19395 from GGU 217715. Frederick E. Hyde Fjord, Johannes V. Jensen Land. L. Paracardiograptus sp. MGUH 19396 from GGU 53485. Kap Bopa, Peary Land. M. Isograptus caduceus australis Cooper. MGUH 19397 from GGU 217716. Frederick E. Hyde Fjord, Johannes V. Jensen Land. N. Distal fragment of Pseudotrigonograptus ensiformis (Hall) MGUH 19398 from GGU 217759. Western Peary Land. O. Cryptograptus cf. C. inuitilis Hall. MGUH 19399 from GGU 217759. Nordpasset, western Peary Land. P. 'Climacograptus' cf. C. riddellensis Harris. MGUH 19400 from GGU 217727. Vølvedal, Johannes V. 

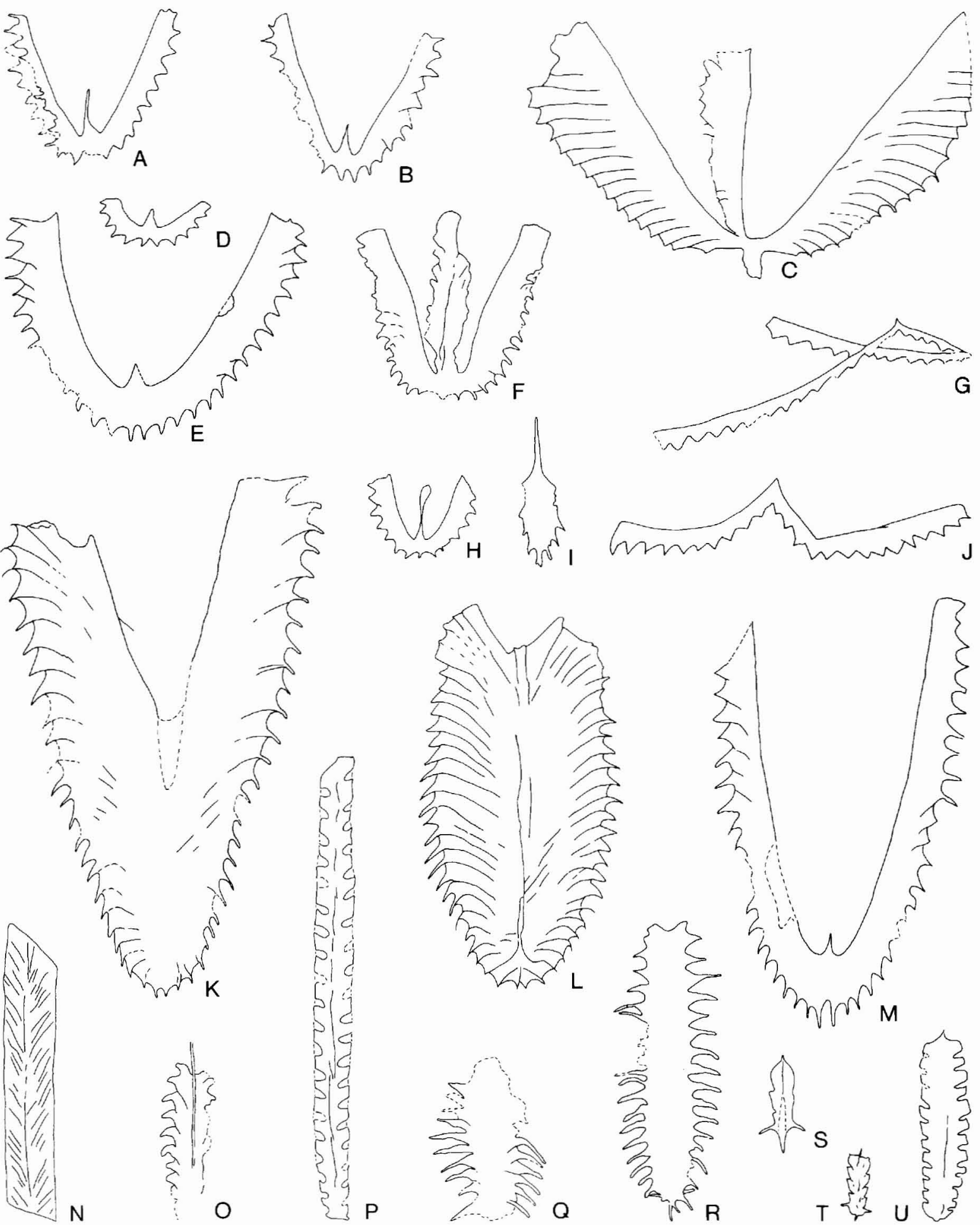

Jensen Land. Q., R. Paraglossograptus tentaculatus (Hall). Q. MGUH 19401 from GGU 217759. Nordpasset, western Peary Land. R. MGUH 19402 from GGU 311244. Navarana Fjord, Lauge Koch Land. S. Cryptograptus cf. C. tricornis Carruthers. MGUH 19403 from GGU 217727. Frederick E. Hyde Fjord, Johannes V. Jensen Land. T. Oelandograptus? austrodentatus (Harris \& Keble). MGUH 19404 from GGU 311244. Navarana Fjord, Lauge Koch Land. U. 'Climacograptus'? differtus Harris \& Thomas. MGUH 19405 from GGU 319803. Northern Nyeboe Land. All figures $\times 3$. 
graphical significance. Only $I$. victoriae victoriae and Pseudisograptus hastatus (Harris) were reported by Williams \& Stevens (1988) to have their first occurrence at this level.

\section{? Isograptus victoriae maximus Zone}

The I. victoriae maximodivergens Zone of Cooper (1979a) (Ca3) and Lenz \& Jackson (1986), corresponding to the lower part of the I. victoriae maximus Zone of Williams \& Stevens (1988), cannot be proved with certainty in North Greenland as the index species has not been recorded. The level is probably represented by graptolites in two samples. One sample (GGU 217807) contains Isograptus ex gr. victoriae Harris and Isograptus? dilemma Williams \& Stevens (figs 5D, H) (= Didymograptus cf. D. hemicyclus of Cooper 1973). The other sample (GGU 217760) includes proximal specimens of $I$. ex gr. victoriae together with a fauna of Paradelograptus?, Xiphograptus ?declinatus Williams \& Stevens (fig. 5J), Xiphograptus sp. and Goniograptus sp.

\section{Oncograptus Zone}

The Oncograptus Zone, which is here supposed to correspond to the Yukon Oncograptus Zone (Lenz \& Jackson, 1986), is sparsely represented and there is no possibility of subdivision. The index genus is observed only in one sample (GGU 217715), represented by Oncograptus upsilon biangulatus Harris \& Keble (fig. 5K); Paracardiograptus sp. (fig. 5L) and Cardiograptus sp. are also found in one sample (GGU 53485). Other species probably representing this level are Isograptus caduceus australis Cooper (fig. 5M), Isograptus caduceus s.l. (Salter), I.? dilemma and Skiagraptus ?gnomonicus (Harris \& Keble) (fig. 5I). Cardiograptus and Oncograptus are not present in Newfoundland (Williams \& Stevens, 1988) and in the northern part of the Canadian Cordillera (Lenz \& Jackson, 1986). The occurrence of Cardiograptus and Oncograptus might be facies controlled. The present samples are from slope facies in northern Nyeboe Land, and from the trough sequence in Johannes V. Jensen Land and at Kap Bopa,
Peary Land. These genera, which are confined to the oceanic isograptid fauna (according to Fortey \& Cocks, 1986), are also preserved in deposits from the deeper parts of the basin in North Greenland.

\section{Paraglossograptus tentaculatus Zone}

The base of the zone is generally defined as the incoming of biserial graptolites together with the zone fossil (Lenz \& Jackson, 1986; Williams \& Stevens, 1988). The zone is correlated with the Australasian $O . ?$ austrodentatus Zone, Da1, and the G. intersitus Zone, Da2. Available faunas indicative of this zone are sparse, and a subdivision into the two Australasian zones is not possible.

Oelandograptus? austrodentatus (Harris \& Keble) (fig. 5T) has been observed in two samples (GGU 217759 and 311244), together with Paraglossograptus tentaculatus (Hall) (figs 5Q, R) (the present specimens are similar to $P$. cf. tentaculatus described by Cooper (1979a)), Didymograptus cf. D. cognatus Harris \& Keble, Pseudotrigonograptus ensiformis (Hall) (fig. $5 \mathrm{~N}$ ), Cryptograptus cf. C. tricornis Carruthers, Cryptograptus cf. C. inuitilis Hall (fig. 5O), Cryptograptus sp., 'Climacograptus' ?modicellus (Harris \& Thomas), 'Climacograptus' cf. C. riddellensis Harris, Pseudoamplexograptus cf. P. confertus (Lapworth) and 'Diplograptus' sp. Cardiograptus, Oncograptus and Isograptus caduceus continue into the lower part of the O.? austrodentatus Zone in Australia (VandenBerg in Webby et al., 1981) and it is possible that the samples with these genera might instead indicate the base of the Darriwilian.

\section{?' Diplograptus' decoratus Zone}

This zone level is hardly recognisable in North Greenland. Only one sample (GGU 217727) includes a specimen probably referable to 'Diplograptus' decoratus Harris \& Thomas, similar to the specimen figured in Lenz \& Jackson (1986, fig. 10S). Further associates are Didymograptus?, Cryptograptus cf. C. tricornis (Carruthers) (fig. 5S) and the long-ranging ' $C$.' riddellensis (fig. 5P).

Fig. 6. A. Cryptograptus schaferi Lapworth. MGUH 19406 from GGU 311244. Navarana Fjord, Lauge Koch Land. B. Hustedograptus teretiusculus (Hisinger). MGUH 19407 from GGU 313175. Navarana Fjord, Freuchen Land. C. Kalpinograptus lyra (Ruedemann). MGUH 19408 from GGU 313117. J. P. Koch Fjord. D. Reteograptus geinitzianus Hall. MGUH 19409 from GGU 313175. Navarana Fjord, Freuchen Land. E. Pseudoamplexograptus cf. P. maxwelli (Decker). MGUH 19410 from GGU 313118. J. P. Koch Fjord. F. Hallograptus sp. MGUH 19411 from GGU 313118. J. P. Koch Fjord. G. Hallograptus mucronatus (Hall). MGUH 19412 from GGU 313118. J. P. Koch Fjord. H. Cryptograptus insectiformis Ruedemann. MGUH 19413 from GGU 313023. western Peary Land. I. Hallograptus?. MGUH 19414 from GGU 313023. Western Peary Land. J. Dicranograptus cf. D. nicholsoni Hopkinson. MGUH 19415 from GGU 313023. Western Peary Land. K. Glyptograptus brevis (Elles \& Wood). 


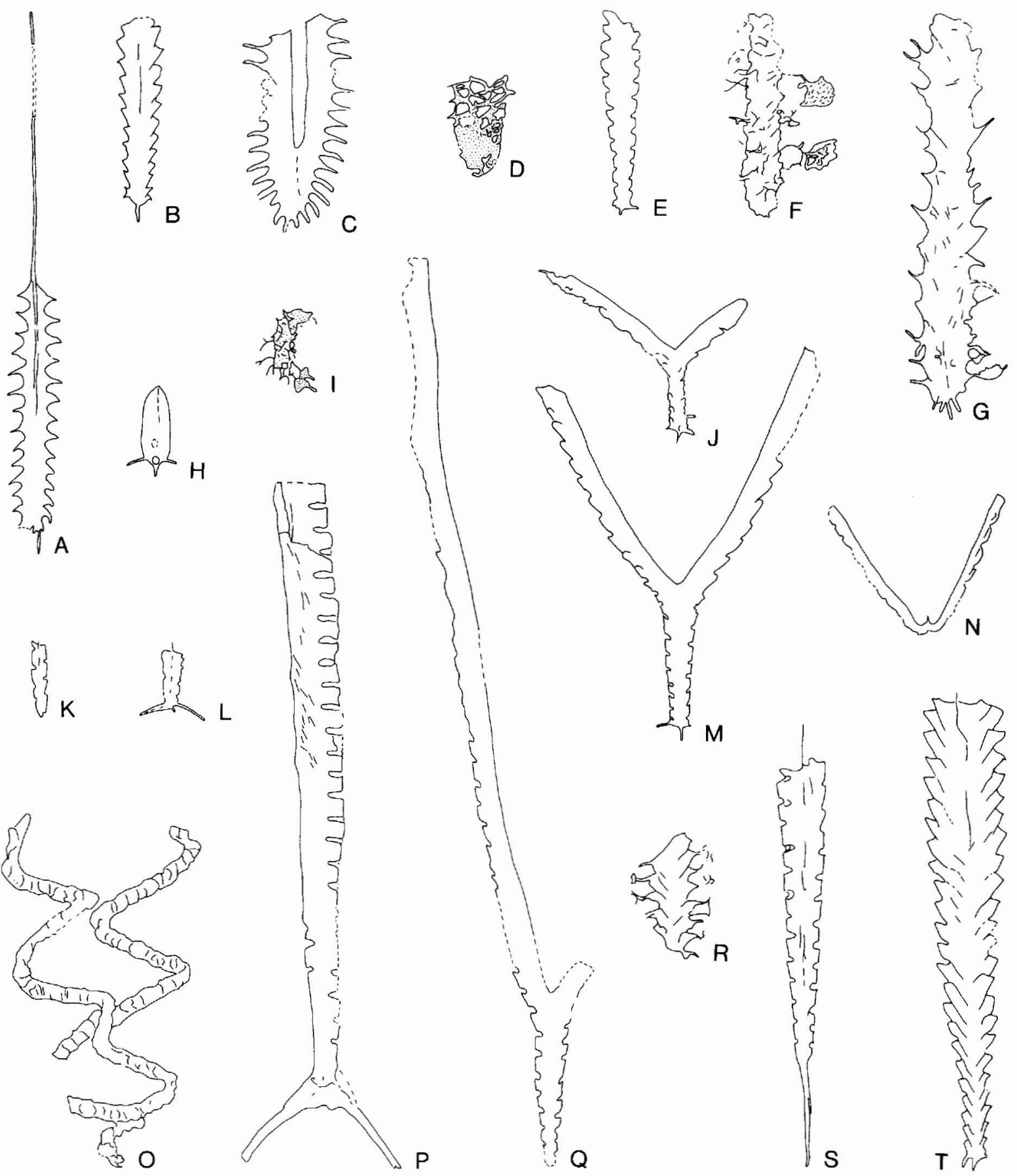

MGUH 19416 from GGU 313023. Western Peary Land. L., P. Climacograptus (Climacograptus) bicornis (Hall). From GGU 313118, J. P. Koch Fjord. L. MGUH 19417. P. MGUH 19418. M. Dicranograptus nicholsoni Hopkinson. MGUH 19419 from GGU 313023. Western Peary Land. N. Dicellograptus ef. D. pumilis Lapworth. MGUH 19420 from GGU 313110. Wulff Land. O. Dicranograptus contortus Ruedemann. MGUH 19421 from GGU 313118. J. P. Koch Fjord. Q. Dicranograptus ramosus (Hall). MGUH 19422 from GGU 313176. Kap Bopa, Peary Land. R. Neurograptus magaritatus (Lapworth). MGUH 19423 from GGU 313023. Western Peary Land. S. Climacograptus (Climacograptus) caudatus Lapworth. MGUH 19424 from GGU 313023. Western Peary Land. T. Orthograptus amplexicaulis (Hall). MGUH 19425 from GGU 313023. Western Peary Land. All figures $\times$ 3. 


\section{? Hustedograptus teretiusculus Zone}

Like the underlying zone level, the $H$. teretiusculus Zone is very poorly represented in North Greenland. Only GGU 313175 contains a faunal assemblage which might be referred to this level: Didymograptus cf. D. compressus Harris \& Thomas (fig. 5G), and Glossograptus ?hincksii Hopkinson, Hustedograptus teretiusculus (Hisinger) (fig. 6B), 'C.' riddellensis and Reteograptus geinitzianus Hall (fig. 6D). However, this assemblage continues into the overlying $N$. gracilis Zone (Webby et al., 1981, fig. 2; Lenz \& Chen, 1985). In the latter paper a $G$. euglyphus Zone was recognised instead of the $H$. teretiusculus Zone on account of the very frequent occurrence of the index species. The fauna in North Greenland is here dissimilar to that of the northern Canadian Cordillera as G. euglyphus has not been observed. However, the present material from this level is too sparse to permit definite conclusions.

\section{Nemagraptus gracilis Zone}

The $N$. gracilis Zone is recognised world wide and characterized by the disappearance of the Pacific graptolite faunas and the establishment of more cosmopolitan faunas. This level can also be recognised in North Greenland, although Nemagraptus gracilis (Hall) has not been seen. GGU 313117 includes a fauna which most likely can be referred to this level. Kalpinograptus ly ra (Ruedemann) (fig. 6C) is especially indicative since it has only been reported from this level (Lenz \& Chen, 1985; Finney, 1986). It is associated with Cryptograptus sp., G. ?hincksii, Pseudoclimacograptus sp., 'C.' riddellensis, Glyptograptus brevis (Elles \& Wood), 'Glyptograptus' sp. and $R$. geinitzianus which have earlier been reported from this zone (e.g. VandenBerg in Webby $e t$ al., 1981).

The Greenland material referred to the $N$. gracilis Zone does not include any representatives of the dicellograptids which are usually registered from this zone (e.g. VandenBerg in Webby et al., 1981; Lenz \& Chen, 1985). However, the present material is too small for any further interpretation of the absence of slender forms such as Nemagraptus and Dicellograptus.

\section{Climacograptus bicornis Zone}

The $C$. bicornis Zone is here tentatively distinguished as a separate zone following Churkin \& Carter (1977) and Lenz \& Chen (1985) and not as a subzone of $N$. gracilis (Finney, 1986). Following Lenz \& Chen (1985) the C. bicornis Zone level in North Greenland is defined by the presence of Climacograptus (Climacograptus) bicornis (Hall) (figs 6L, P) which is frequent in GGU 313118. Accompanying species are Dicranograptus contortus Ruedemann (fig. 6O), Pseudoclimacograptus (Pseudoclimacograptus) ex gr. scharenbergi (Lapworth), Pseudoamplexograptus cf. maxwelli (Decker) (fig. 6E), Hallograptus mucronatus (Hall) (fig. 6G), Hallograptus sp. (fig. 6F), Hallograptus? (fig. 6I). 'Climacograptus' ?differtus Harris \& Thomas (fig. $5 \mathrm{U}$ ) is possibly referable to this level. Unless the present graptolites have ranges other than earlier reported (e.g. by Finney, 1986), the $N$. gracilis and $C$. bicornis faunas are distinct in North Greenland.

The C. bicornis Subzone was correlated with the British $D$. multidens Zone (equivalent to the $C$. peltifer and C. wilsoni zones) by Finney (1986). In Australia a separate $C$. bicornis Zone has not been distinguished and C. bicornis occurs in the upper part of the $N$. gracilis Zone and in the $O$. calcaratus Zone (Cas \& VandenBerg, 1988).

\section{? Orthograptus amplexicaulis Zone}

The D. clingani Zone in the Canadian Cordillera was placed tentatively very closely above the $C$. bicornis Zone by Lenz \& Chen (1985); the D. clingani Zone in this area appeared here to be older than the British $D$. clingani Zone. There was no sign of a $D$. multidens Zone and an apparent gap in the faunas between the $D$. clingani and $O$. quadrimucronatus zones was described.

In North Greenland there is no direct evidence for the $D$. multidens and the D. clingani Zones; both index species are lacking. However, in two samples (GGU 313023 , 313176) an assemblage has been recorded which correlates well with faunas earlier reported from the $D$. clingani Zone recently described by Williams \& Bruton (1983) and Finney (1986). The graptolite species are: Cryptograptus insectiformis Ruedemann (fig. 6H), Corynoides americanus Ruedemann, Dicranograptus ramosus (Hall) (fig. 6Q), Dicranograptus nicholsoni Hopkinson (fig. 6M), Dicranograptus cf. D. nicholsoni (fig. 6J), Climacograptus (Climacograptus) caudatus Lapworth (fig. 6S), G. brevis (fig. 6K), Orthograptus amplexicaulis (Hall) (fig. 6T), Orthograptus quadrimucronatus (Hall) (figs 7A, B), Orthograptus ?ruedemanni (Gurley) and Neurograptus magaritatus (Lapworth) (fig. 6R). This suggests that there is no large gap in the North Greenland sequence. It is possible that the revised North American zonation (Finney, 1986) might also be applied to North Greenland. According to Finney (1986) the sequence $N$. gracilis $-O$. amplexicaulis Zones fills the gap earlier supposed for the North 
American sequence. As the present faunal assemblages are in agreement with those reported by Finney (1986), his zonal division has been used.

\section{Orthograptus quadrimucronatus Zone}

The use of this zone is in accordance with practice in the Canadian Cordillera (Lenz \& Chen, 1985). The $C$. tubuliferus Zone was defined by Finney (1986) from North America as roughly corresponding to the P. linearis Zone in the British sequence (Williams, 1982a). Graptolite species reported from the above-mentioned areas from this level are observed in at least four samples from North Greenland and comprise: $C$. (C.) caudatus and Climacograptus (Climacograptus) tubuliferus Lapworth (fig. 3E) (the two species are occasionally indistinguishable from each other), together with Dicellograptus alector Carter \& Churkin, Dicellograptus ?elegans (Carruthers), G. brevis, 'Climacograptus' ?typicalis Hall, Orthograptus ex gr. calcaratus (Lapworth), Orthograptus pauperatus Elles \& Wood, O. amplexicaulis and Orthoretiolites? pulcherrimus (Harris \& Keble). $O$. ?pulcherrimus and $D$. alector are also reported from younger strata (Thomas, 1960; Carter \& Churkin, 1977).

The graptolite fauna from this level is very similar to that reported from the Canadian Cordillera, except that Pleurograptus linearis (Carrruthers), which indicates this level, has not been observed in the present material.

$O$. quadrimucronatus and $O$. amplexicaulis are regarded as unsuitable index species for the two zones; their ranges appear to be fairly wide and for the most part the two species overlap (see also Finney, 1986). However, the present material is far too sparse to serve as a basis of revision of the two zones.

\section{Dicellograptus ornatus Zone}

Samples (GGU 313103, 319683, 319684) containing Dicellograptus ornatus Elles \& Wood (fig. 7K), Dicellograptus minor Toghill, Dicellograptus complexus Davies (figs 7H, J), Climacograptus (Climacograptus) hastatus Hall (fig. $7 \mathrm{~N}$ ) and Climacograptus (Diplacanthograptus) ex gr. longispinus Hall (figs $7 \mathrm{M}, \mathrm{O}$ ) are here regarded as indicators of the $D$. ornatus Zone in the lower Bolindian. It has not been possible to distinguish a special 'Climacograptus' uncinatus Zone corresponding to Bo1 in the Australian sequence. Additional associates are Pleurograptus?, Leptograptus sp. (fig. 7G), Dicellograptus cf. D. pumilis Lapworth (fig. 6N), Climacograptus sp., Orthograptus abbreviatus Elles \& Wood and Orthograptus socialis Lapworth (fig. 7F).
Orthograptus ex gr. calcaratus (fig. 7Q), O.? pulcherrimus (fig. 7C) and D. alector (fig. 7D) apparently continue into this level. Two specimens of an unknown form within the Dicranograptinae, possibly resembling Diceratograptus (fig. 7I), have also been found. The stratigraphical position of Climacograptus cf. C. (Diplacanthograptus) dorotheus Riva (fig. 7E) is uncertain.

It is not possible to correlate the present material to more precise levels, such as those observed in the Australian Bolindian zonation (fig. 2), where 'Climacograptus' uncinatus Churkin \& Carter and O.? pulcherrimus appear to be restricted to the lower part and $D$. ornatus to the upper part of the stage. Williams (1987) correlated the British $D$. complanatus and $D$. anceps Zones with the Australian ' $C$.' uncinatus and $D$. ornatus \& $C$. latus Zone. Williams (1982b) distinguished two upper subzones in the $D$. anceps Zone, the $D$. complexus and the $P$. pacificus Subzones. The presence of $D$. complexus in the present material could indicate the upper part of the D. ornatus Zone but the material is limited to one sample only.

The North Greenland D. ornatus assemblage correlates with the equivalent zone in the Canadian Cordillera (Lenz \& McCracken, 1982; Lenz \& Chen, 1985). Also in Canada it is not clear whether the D. ornatus Zone comprises most of the Bolindian or only the lower part (Lenz \& Chen, 1985).

It is remarkable that the North Greenland late Ordovician graptolite faunas include numerous dicellograptids, as do those from the Canadian Cordillera (Lenz \& McCracken, 1982; Lenz \& Chen, 1985). This contrasts with graptolite faunas described by Melchin (1987) from the Cape Phillips Formation in Arctic Canada where the dicellograptids are absent. At this stratigraphic level only an $O$. fastigatus Zone was reported by Melchin (1987).

\section{? Parorthograptus pacificus Zone}

The $P$. pacificus Zone was distinguished as a separate zone in the northern Canadian Cordillera by Lenz \& McCracken (1982). In other areas the level with Parorthograptus pacificus (Ruedemann) (fig. 7L) has been defined as the uppermost subzone of the $D$. anceps Zone (Williams, 1982b) or as the uppermost subzone in the C. supernus Zone (Koren et al., 1979).

In North Greenland $P$. pacificus has only been observed in two samples of which GGU 313135 is not in situ. It is associated with $C$. longispinus, Geniculograptus ?latus (Elles \& Wood) (fig. 7R), Arnheimograptus lorrainensis (Ruedemann) (fig. 7P) and Orthograptus sp.

The $P$. pacificus level is apparently the youngest Or- 

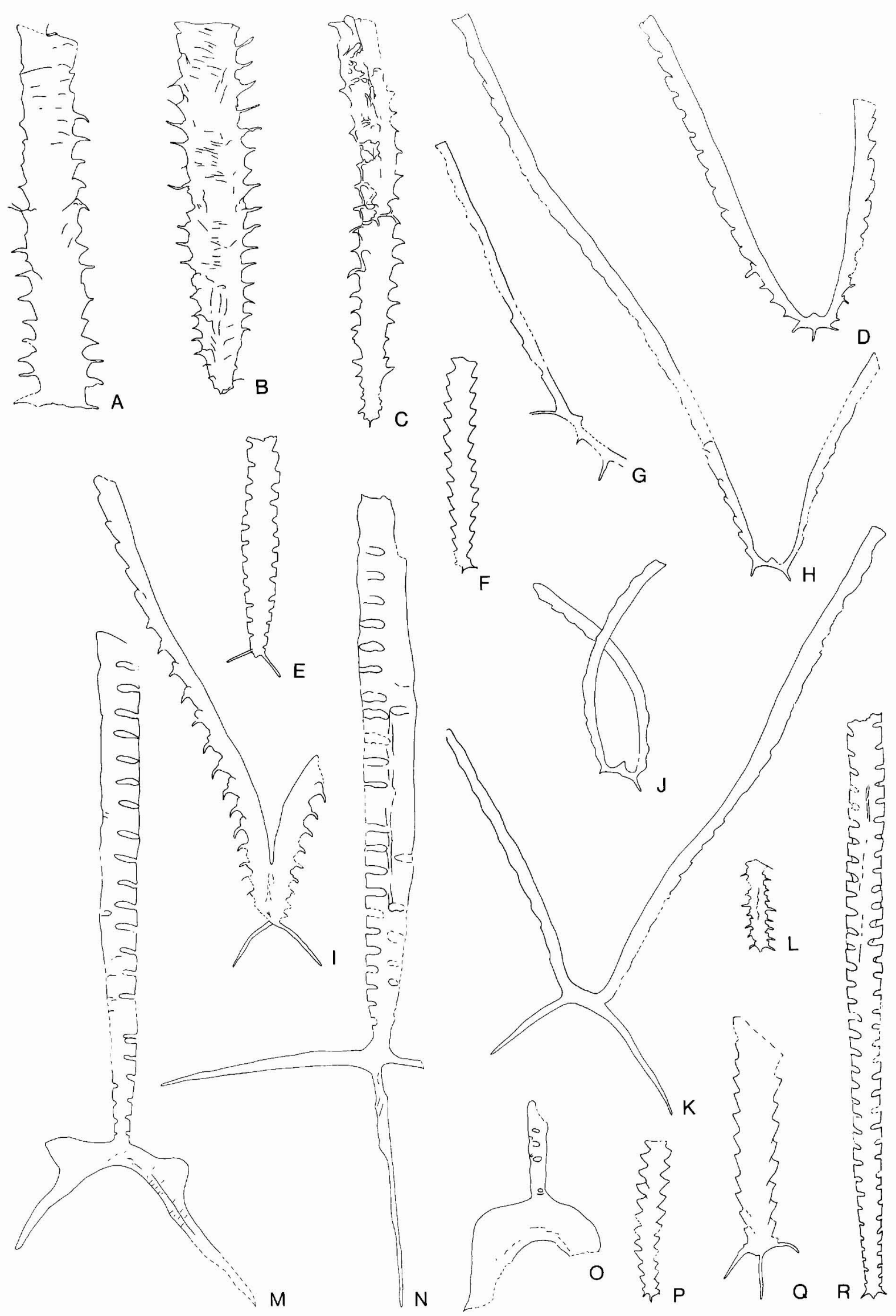
dovician present in the available graptolite collections from North Greenland. Neither the $C$. extraordinarius Zone (Williams, 1982b) nor the G. persculptus Zone have been observed in North Greenland, and the Ordovician-Silurian boundary cannot be demonstrated by graptolites. The earliest Silurian graptolites are from the trough sequence in Johannes V. Jensen Land where a sparse fauna from the $C$. atavus $-C$. cyphys Zones is recorded (Surlyk et al., 1981).

One sample from the Aleqatsiaq Fjord Formation exposed along the southern part of Newman Bugt in western North Greenland contains Geniculograptus cf. G. inuiti (Cox). The exact stratigraphic position cannot be indicated, as the type material of $G$. inuiti was reported from a level as low as the $C$. manitoulensis Zone (Riva, 1974), and the possible synonymy with $G$. latus (Riva, 1986) indicates a long range, corresponding to both the D. ornatus and $P$. pacificus Zones.

\section{Discussion of the graptolite biofacies}

The North Greenland Ordovician graptolites, especially those of Early Ordovician age, are clearly similar to the graptolite faunal assemblages reported from the Canadian Cordillera (Lenz \& Jackson, 1986), Australasia (Thomas, 1960; Cooper, 1979; Webby et al., 1981), Texas (Berry, 1960), the Great Basin area (Ross \& Berry, 1963), Idaho (Carter \& Churkin, 1977), Newfoundland (Williams et al., 1987; Williams \& Stevens, 1988), Spitzbergen (Cooper \& Fortey, 1982) and parts of southern China (Sheng, 1980). These regions are traditionally referred to the 'Pacific' faunal realm.

Ordovician graptolites in North Greenland are found in outer slope and deep-water trough sediments within the Franklinian Basin. These clastic deposits are now exposed in eastern parts of North Greenland in Johannes V. Jensen Land and Amundsen Land, and in western parts of North Greenland in the northern pen- insulas of Nyeboe Land, Wulff Land, Nares Land and Freuchen Land (e.g. Higgins et al., in press; fig. 1).

Throughout the Ordovician sequences in North Greenland the graptolite faunas are similar to the assemblages referred to as the 'oceanic' graptolite biofacies (Fortey, 1984) and to those reported as originating from deep-water facies (Lenz \& Chen, 1985; Finney, 1986). The earliest Ordovician fauna recorded here is an anisograptid assemblage. This assemblage is usually present in deposits interpreted to be from marginal oceanic areas, e.g. Lancefield, Victoria (Cooper \& Stewart, 1979), Peel River (Jackson, 1974, 1975; Erdtmann, 1988).

The basal Arenig T. approximatus Zone is characteristic of oceanic facies, e.g. in the Victorian sequence (Fortey, 1984), and is absent in shallow water deposits, as described from the Arenig type area deposits in Wales (Molyneux \& Rushton, 1988).

During the interval Arenig-Llanvirn the oceanic isograptid biofacies (Fortey, 1984) prevailed in North Greenland, characterised by the presence of Isograptus, Oncograptus and Cardiograptus, together with representatives of the slender many-stiped 'dichograptids' such as Goniograptus and Sigmagraptus.

During the Llandeilo-Caradoc the graptolite faunas became more cosmopolitan, probably as a result of the world-wide transgression (Fortey, 1984) or, as traditionally supposed, by the breakdown of the boundaries of the faunal provinces in connection with the closure of the Iapetus Ocean. However, during the Caradoc there are faunal differences in North America, described for example by Finney (1986). In this connection it is significant that the graptolite faunas from North Greenland are most similar to the $O$. quadrimucronatus - C. tubuliferus assemblage, reported from Nevada and Idaho, originating from deeper water deposits away from the craton. They are different from the post-gracilis C. manitoulens $-C$. pygmeus forms of the northern Appa-

Fig. 7. A., B. Orthograptus quadrimucronatus (Hall). From GGU 313023. Western Peary Land. A. MGUH 19426. B. MGUH 19427. C. Orthoretiolites? pulcherrimus (Harris \& Keble). MGUH 19428 from GGU 313103. Nares Land. D. Dicellograptus alector Carter \& Churkin. MGUH 19429 from GGU 313103. Nares Land. E. Climacograptus cf. C. (Diplacanthograptus) dorotheus Riva. MGUH 19430 from GGU 313135. Southern side of Kap Bopa, Peary Land. F. Orthograptus socialis Lapworth. MGUH 19431 from GGU 313103. Nares Lanủ. G. Leptograptus sp. MGUH 19432 from GGU 319683. Nares Land. H., J. Dicellograptus complexus Davies. From GGU 319683, Nares Land. H. MGUH 19433. J. MGUH 19434. I. Dicranograptine, gen. nov.? MGUH 19435 from GGU 319683. Nares Land. L. Parorthograptus pacificus (Ruedemann). MGUH 19436 from GGU 313135. Southern side of Kap Bopa, Peary Land. K. Dicellograptus ornatus Elles \& Wood. MGUH 19437 from GGU 319684. Nares Land. M., O. Climacograptus (Diplacanthograptus) longispinus Hall. M. MGUH 19438 from GGU 319684. Nares Land. O. MGUH 19439 from GGU 313135. Southern side of Kap Bopa, Peary Land. N. Climacograptus (Climacograptus) hastatus Hall. MGUH 19440 from GGU 319683. Nares Land. P. Arnheimograptus lorrainensis (Ruedemann). MGUH 19441 from GGU 313135. Southern side of Kap Bopa, Peary Land. Q. Orthograptus ex gr. calcaratus (Lapworth). MGUH 19442 from GGU 319683 . Nares Land. R. Geniculograptus ?latus (Elles \& Wood). MGUH 19443 from GGU 313101. Nares Land. All figures $\times 3$. 
lachians in the eastern part of North America, as described by Riva (1974).

The late Ordovician graptolite assemblages of North Greenland include numerous dicellograptids, as do those from the Canadian Cordillera (Lenz \& McCracken, 1982; Lenz \& Chen, 1985). These faunas differ from the graptolite assemblages reported from the Cape Phillips Formation in Arctic Canada which lack the dicellograptids (Melchin, 1987). In the Cape Phillips Formation the graptolites occur in taphocoenoses from moderate to deep shelf areas at the margin of the Franklinian Basin, and not from the outer slope environment of the graptolitiferous strata in the western areas of North Greenland (Higgins et al., in press). As also mentioned by Melchin (1987) the presence of the dicellograptids might be ecologically dependent on, for example, different water masses or basin depth.

In conclusion the North Greenland Ordovician graptolite faunas represent taphocoenoses from deep oceanic, either slope or trough clastic sediments, which border shelf sequences developed around the North American craton. They agree well with the earlier recorded oceanic graptolite biofacies, recognised on the margins of former continents, as described and figured by Fortey \& Cocks (1986, fig. 3).

Acknowledgements. I thank P. R. Dawes, A. K. Higgins, J. M. Hurst, S. Schack Pedersen, F. Rolle, M. Sønderholm and F. Surlyk for allowing me to work on their graptolite collections, and I am indebted to A. K. Higgins, F. Surlyk and S. Schack Pedersen for providing most of the material and for information on the geology of the area. I have benefited from discussions of a number of graptolites with K. Lindholm (Lund, Sweden). J. S. Peel is thanked for critical reading and improving the English of the manuscript. Thanks are directed to $\mathrm{R}$. Larsen and A. Andersen for drawing the map and the scheme.

\section{References}

Berry, W. B. N. 1960: Graptolite faunas of the Marathon region, West Texas. Univ. Texas Pub. 6005, 179 pp.

Bjerreskov, M. 1988: The Ordovician graptolite sequences in North Greenland. 5th Int. Symp. Ordovician System, Abstracts, 10 only.

Bjerreskov, M. \& Poulsen, V. 1973: Ordovician and Silurian faunas from northern Peary Land, North Greenland. Rapp. Grønlands geol. Unders. 55, 10-14.

Carter, C. \& Churkin, M., Jr. 1977: Ordovician and Silurian graptolite succession in the Trail Creek area, central Idaho a graptolite reference section. U.S. Geol. Surv. Prof. Pap. 1020, 37 pp.

Carter, C. \& Tailleur, I. L. 1984: Ordovician graptolites from the Baird Mountains, western Brooks Range, Alaska. J. Paleont. 58, 40-57.
Cas, R. A. F. \& VandenBerg, A. H. M. 1988: Ordovician. In Douglas, J. G. \& Ferguson, J. A. (edit.) Geology of Victoria, 63-102. Melbourne: Victorian Division, Geological Society of Australia Incorporated.

Chen, X. \& Lenz, A. C. 1984: Ordovician graptolite zonation and correlation with specific reference to the Pacific faunal realm. Neues Jb. Geol. Paläont. Mh. 4, 212-222.

Cooper, R. A. 1979a: Ordovician geology and graptolite faunas of the Aorangi Mine area, north west Nelson, New Zealand. Palaeont. Bull. N.Z. geol. Surv. 47, $127 \mathrm{pp}$.

Cooper, R. A. 1979b: Sequence and correlation of Tremadoc graptolite assemblages. Alcherringa 3, 7-19.

Cooper, R. A. \& Fortey, R. A. 1982: The Ordovician graptolites of Spitsbergen. Bull. Br. Mus. nat. Hist. (Geol.) 36, 171 pp.

Cooper, R. A. \& Stewart, I. R. 1979: The Tremadoc graptolite sequence in Lancefield, Victoria. Palaeontology 22, 767797.

Cowie, J. W. 1961: The Lower Palaeozoic geology of Greenland. In Raasch, G. O. (edit.) Geology of the Arctic 1, 160-169. Toronto U.P.

Dawes, P. R. \& Soper, N. J. 1970: Geological investigations in northern Peary Land. Rapp. Grønlands geol. Unders. 28, 9-15.

Erdtmann, B.-D. 1988: The earliest Ordovician nematophorid graptolites: taxonomy and correlation. Geol. Mag. 125(4), 327-348.

Finney, S. C. 1986: Graptolite biofacies and correlation of eustatic, subsidence, and tectonic events in the Middle to Upper Ordovician of North America. Palaios 1, 435-461.

Fortey, R. A. 1984: Global earlier Ordovician transgressions and regressions and their biological implications. In Bruton, D. L. (edit.) Aspects of the Ordovician System. Palaeont. Contrib. Univ. Oslo 295, 37-50.

Fortey, R. A. \& Cocks, L. R. M. 1986: Marginal faunal belts and their structural implications, with examples from the Lower Palaeozoic. J. geol. Soc. Lond. 143, 151-160.

Fortey, R. A. \& Owens, R. M. 1987: The Arenig series in South Wales. Bull. Br. Mus. nat. Hist. (Geol.) 41(3), 69-308.

Friderichsen, J. D., Higgins, A. K., Hurst, J. M., Pedersen, S. A. S., Soper, N. J., and Surlyk, F. 1982: Lithostratigraphic framework of the Upper Proterozoic and Lower Palacozoic deep water clastic deposits of North Greenland. Rapp. Grønlands geol. Unders. 107, $19 \mathrm{pp}$.

Higgins, A. K., Ineson, J. R., Peel, J. S., Surlyk, F. \& Sønderholm, M. (in press): The Franklinian Basin in North Greenland. D-NAG Spec. Publ.

Higgins, A. K. \& Soper, N. J. 1985: Cambrian - Lower Silurian slope and basin stratigraphy between northern Nyeboe Land and western Amundsen Land, North Greenland. Rapp. Grønlands geol. Unders. 126, 79-86.

Ineson, J. R. \& Peel, J. S. (in press): Cambrian stratigraphy of North Greenland. Bull. Grønlands geol. Unders.

Jackson, D. E. 1974: Tremadocian graptolites from Yukon Territory, Canada. Spec. Pap. Palaeont. 13, 35-58.

Jackson, D. E. 1975: New data on Tremadoc graptolites from Yukon, Canada. Palaeontology 18, 883-887. 
Koren, T. N., Sobolevskaya, R. F., Mikhailova, N. F. \& Tsai, D. T. 1979: New evidence on graptolite succession across the Ordovician-Silurian boundary in the Asian Part of USSR. Acta palaeont. pol. 24, 125-136.

Lenz, A. C. 1988: Ordovician Series/Stages, Graptolitic Basinal Facies, northern Yukon, Canada. The Canadian Paleontology \& Biostratigraphy seminar. N.Y. State Mus. Bull. 462, 59-64.

Lenz, A. C. \& Chen, X. 1985: Middle and Upper Ordovician graptolite biostratigraphy of Peel River and other areas of the northern Canadian Cordillera. Can. J. Earth Sci. 22, 227-239.

Lenz, A. C. \& Jackson, D. E. 1986: Arenig and Llanvirn graptolite biostratigraphy, Canadian Cordillera. In Hughes, C. P. \& Rickards, R. B. (edit.) Palaeontology and biostratigraphy of graptolites. Spec. Publ. geol. Soc. Lond. 20, $27-45$.

Lenz, A. C. \& McCracken, A. D. 1982: The OrdovicianSilurian boundary, northern Canadian Cordillera: graptolite and conodont correlation. Can. J. Earth Sci. 19, 1308-1322.

Melchin, M. J. 1987: Upper Ordovician graptolites from the Cape Philips Formation, Canadian Arctic Islands. Bull. geol. Soc. Denmark 35, 191-202.

Mitchell, C. E. 1987: Evolution and phylogenetic classification of the Diplograptacae. Palaentology 30, 353-405.

Molyneux, S. \& Rushton, A. 1988: Latest Tremadoc-earliest Arenig sediments in England and Wales: their bearing in the definition and correlation of the base of the Arenig Series. 5th Int. Symp. Ordovician System, Abstracts, 62 only.

Peel, J. S. 1982: The Lower Paleozoic of Greenland. In Embry, A. F. \& Balkwill, H. R. (edit.) Arctic geology and geophysics. Can. Soc. Petrol. Geol. Mem. 8, 309-330.

Poulsen, C. 1927: The Cambrian, Ozarkian and Canadian faunas of Northwest Greenland. Meddr Grønland 70(1), 233343.

Riva, J. 1974: A revision of some graptolites of eastern North America. Palaeontology 17, 1-40.

Riva, J. 1986: The graptolite Amplexograptus praetypicalis $\mathbf{n}$. sp. and the origin of the typicalis group. Can. J. Earth Sci. 24, 924-933.

Ross, R. J., Jr., Adler, F. J., Amsden, T. W., Bergstrom, D., Bergstrom, S. M. et al. 1982: The Ordovician System in the United States, correlation chart and explanatory notes. Int. Un. geol. Sci. Publ. 12, 73 pp.
Ross, R. J. \& Berry, W. B. N. 1963: Ordovician graptolites of the Basin Ranges in California, Nevada, Utah and Idaho. U.S. geol. Surv. Bull. 1134, 177 pp.

Sheng, S. 1980: The Ordovician System of China. Int. Un. geol. Sci. Publ. 1, 1-7.

Sønderholm, M., Harland, T. L., Due, P. H., Jørgensen, L. N. \& Peel, J. S. 1987. Lithostratigraphy and depositional history of Upper Ordovician - Silurian shelf carbonates in central and western North Greenland. Rapp. Grønlands geol. Unders. 133, 27-40.

Surlyk, F. \& Hurst, J. M. 1984: The evolution of the early Paleozoic deep-water basin of North Greenland. Geol. Soc. Amer. Bull. 95, 131-154.

Surlyk, F., Hurst, J. M. \& Bjerreskov, M. 1980: First agediagnostic fossils from the central part of the North Greenland foldbelt. Nature 286, 800-803.

Thomas, D. E. 1960: The zonal distribution of Australian graptolites. J. Proc. R. Soc. New South Wales 94, 1-58.

Trettin, H. P. \& Balkwill, H. R. 1979: Contributions to the tectonic history of the Innuitian Province, Arctic Canada. Can. J. Earth Sci. 16, 748-769.

Webby, B. D., VandenBerg, A. H. M., Cooper, R. A., Banks, M. R., Burrett, C. F., Henderson, R. A., Clarkson, P. D., Hughes, C. P., Laurie, J., Stait, B., Thomson, M. R. A. \& Webers, G. F. 1981: The Ordovician System in Australia, New Zealand \& Antarctica. Int. Un. geol. Sci. Publ. 6, 64 pp.

Williams, S. H. 1982a: Upper Ordovician graptolites from the top Lower Hartfell Shale Formation (D. clingani and $P$. linearis zones) near Moffat, Southern Scotland. Trans. $R$. Soc. Edinb., Earth Sci. 72, 229-255.

Williams, S. H. 1982b: The late Ordovician graptolite fauna of the Anceps Bands at Dob's Linn, southern Scotland. Geol. Palaeont. 16, 29-56.

Williams, S. H. \& Bruton, D. L. 1983: The Caradoc-Ashgill boundary in the central Oslo Region and associated graptolite faunas. Norsk geol. Tidsskr. 63, 147-191.

Williams, S. H. \& Stevens, R. K. 1987: Summary account of the Lower Ordovician (Arenig) graptolite biostratigraphy of the Cow Head Group, western Newfoundland. Bull. geol. Soc. Denmark 35, 259-270.

Williams, S. H. \& Stevens, R. K. 1988: Early Ordovician (Arenig) graptolites of the Cow Head Group, western Newfoundland, Canada. Palaeontologr. Canad. 5, 167 pp. 